\title{
Kualitas Silase Rumput Benggala (Panicum maximum) pada Berbagai Taraf Penambahan Bahan Aditif Ekstrak Cairan Asam Laktat Produk Fermentasi Anaerob Batang Pisang
}

\author{
Quality of Guinea Grass Silage at Various Addition of Anaerobic Fermentation of Lactic Acid \\ Extract (LAE) from Banana Pseudo Stem
}

\author{
T. Dhalika, A. Budiman dan Mansyur \\ Fakultas Peternakan Universitas Padjadjaran \\ email : tidi.dhalika@yahoo.com
}

(Diterima: 20 Oktober 2014; Disetujui: 18 Januari 2015)

\begin{abstract}
ABSTRAK
Penelitian ini bertujuan untuk mengetahui pengaruh penambahan ekstrak cairan asam laktat (ECAL) produk fermentasi anaerob batang pisang terhadap kualitas silase rumput Benggala $(P$. maximum). Penelitian dilakukan dengan metode eksperimental menggunakan Rancangan Acak Lengkap, perlakuannya adalah penambahan campuran ekstrak cairan asam laktat produk fermentasi anaerob batang pisang dengan molases pada proses ensilase rumput Benggala, yaitu: (1) P0M100 (0 \% ECAL + $100 \%$ molases), (2) P25M75 (25\% ECAL + $75 \%$ molases), (3) P50M100 (50 \% ECAL $+50 \%$ molases), (4) P75M25 (75 \% ECAL + $25 \%$ molases), (5) P100M0 (100 \% ECAL + $0 \%$ molases), tiap perlakuan diulang sebanyak 4 kali. Peubah yang diukur adalah kualitas fisik dan kimia silase rumput Benggala, meliputi kebersihan, warna, bau, rasa, tekstur, derajat keasaman, kandungan asam laktat, dan $\mathrm{NH}_{3}$. Data yang diperoleh diuji menggunakan analisis ragam dilanjutkan dengan uji Jarak Berganda Duncan. Hasil penelitian menunjukan bahwa penambahan campuran ekstrak cairan asam laktat produk fermentasi batang pisang dengan molases memberikan pengaruh terhadap kualitas fisik dan kimia silase rumput Benggala, dan campuran ekstrak cairan asam laktat produk fermentasi batang pisang dengan molases pada perbandingan $75 \%: 25 \%$ menghasilkan kualitas fisik dan kimia silase rumput Benggala terbaik.
\end{abstract}

Kata kunci: Panicum maximum, cairan asam laktat, molases, silase

\section{ABSTRACT}

An experiment was conducted to study the silage quality of Guinea grass (P. maximum) added by lactic acid extract (LAE) with an anaerobic fermentation product from pseudostem of banana. The experiment used a Completely Randomized Design with 5 treatments and 4 replications. Treatments consisted of following types; (1) POM100 (0 \% LAE $+100 \%$ molasses), (2) P25M75 (25\% LAE + $75 \%$ molasses), (3) P50M100 (50\% LAE + $50 \%$ molasses), (4) P75M25 (75\% LAE + $25 \%$ molasses), and (5) P100M0 (100\% LAE + $0 \%$ molasses). Measured parameters contained both physical and chemical quality of Guinea grass silage i.e; clean, color, odor, taste, level of acidity, content of lactic acid, texture and $\mathrm{NH}_{3}$, Collected data were analized by variant analysis and Duncan Multiple Range Test. The result showed that the usage of lactic acid extract as an anaerobic fermentation products from pseudostem of banana with molasses affected both physical and chemical quality of Guinea grass silage. The best mixture of using lactic acid extract as an anaerobic fermentation from pseudostem of banana with molasses in term of both physical and chemical quality of Guinea grass silage was $75 \%$ compared to $25 \%$.

Keywords: Panicum maximum, lactic acid juice, molasses, silage 


\section{PENDAHULUAN}

Rumput Benggala (Panicum maximum) merupakan salah satu rumput unggul asal Afrika tropika yang sudah cukup lama beradaptasi dan dibudidayakan di Indonesia, dan digunakan untuk kepentingan penyediaan hijauan pakan bagi ternak ruminan. Rumput Panicum maximum dikenal juga dengan nama lain Guinea grass, Buffalo grass, atau green panic. Potensi produksi biomasa rumput Benggala cukup tinggi, berkisar antara 30 ton sampai 115 ton hijauan segar/ha/tahun. Produksi bahan kering hijauan, nilai gizi, palatabilitas dan kecernaan mendekati rumput gajah. Kelebihan rumput Benggala adalah lebih tahan terhadap kekeringan dibandingkan rumput gajah. Produktivitas yang optimum dicapai pada interval pemotongan antara 30 40 hari, setelah umur tersebut tanaman menuju fase pertumbuhan generatif dan produksi daunnya tidak akan bertambah lagi. Produksi bahan kering mencapai 36,70 ton/ha/tahun dengan nilai palatabilitas pada ternak domba $46 \%$ dan konsumsi per ekor sebanyak 537,84 g. (Mc. Ilroy, 1977; Sajimin, et al., 2006).

Produksi rumput Benggala meningkat sangat tinggi pada saat musim hujan, sehingga seringkali terjadi kelebihan produksi biomasa. Sedangkan pada musim kemarau kapasitas produksinya menurun sangat drastis, akibatnya ketersediaan jenis hijauan pakan ini sangat fluktuatif yang menyebabkan pasokan hijauan pakan untuk mendukung pengembangan ternak ruminan sepanjang tahun tidak merata.

Berdasarkan kenyataan tersebut diperlukan upaya pengawetannya agar distribusi hijauan pakan, seperti rumput Benggala dapat tersedia sepanjang tahun sesuai kebutuhan ternak. Salah satu bentuk pengawetan hijauan pakan yang dapat dilakukan adalah dengan aplikasi teknologi ensilage, yaitu suatu cara pengawetan hijauan pakan secara basah dengan metode fermentasi anaerob (Mc Ilroy, 1977; Mc. Donald, 1981; Hartadi et al., 1991). Kelebihan yang dimiliki oleh metode pengawetan ini, diantaranya tidak tergantung pada cuaca, sehingga merupakan cara penga- wetan hijauan pakan yang paling baik dalam kondisi tropik (Mc. Ilroy, 1977; Mc. Donald, 1981).

Keberhasilan proses ensilage dipengaruhi oleh beberapa faktor, diantaranya adalah penambahan bahan aditif. Salah satu bahan aditif yang dapat digunakan adalah asam laktat yang sumbernya dapat diperoleh dari ekstrak cairan fermentasi anaerob yang mengandung bakteri asam laktat. Bakteri asam laktat adalah mikroflora penting pada proses ensilase karena asam laktat yang dihasilkannya dapat memelihara stabilitas zat makanan yang ada didalam bahan pakan sehingga lebih awet dalam proses penyimpanannya. Selain itu, menurut Aritonang et al. (2003), asam laktat yang dihasilkan dapat menekan pertumbuhan mikroba patogen seperti E. Coli, Salmonella, Shigella, Campylobacteria dan Clostridia yang ada di dalam usus dengan cara menurunkan derajat keasaman $(\mathrm{pH})$. Penelitian ini dilakukan untuk mengetahui kualitas rumput Benggala yang diawetkan menggunakan proses ensilage dengan penambahan bahan aditif sebagai sumber bakteri asam laktat.

\section{METODE}

Bahan yang digunakan pada penelitian ini adalah rumput Benggala yang dipanen pada fase berbunga awal, batang pisang jenis ambon yang telah dipanen buahnya, dan molases yang digunakan sebagai bahan aditif pada proses fermentasi anaerob. Alat penelitian terdiri dari timbangan, tong plastik (silo) kapasitas 60 liter, pH meter merk Hanna, cawan Conway, wadah sampel untuk uji organoleptik dan perangkat alat uji kimia untuk mengukur kandungan $\mathrm{NH} 3$ dan asam laktat pada silase rumput Benggala.

\section{Produksi ekstrak cairan asam laktat (ECAL)}

Batang pisang dari jenis pisang ambon yang telah dipanen buahnya, dicacah pada ukuran lebih kurang $5 \mathrm{~cm}$, tebarkan hasil cacahan batang pisang diatas alas plastik secara merata. Timbang cairan molases sebanyak 5\% dari bobot cacahan batang pisang, dan disiramkan secara merata di atas cacahan batang 
pisang, aduk cacahan batang pisang dan molases sampai tercampur merata. Masukan secara bertahap campuran batang pisang dan molases kedalam tong plastik (silo fermentor) kapasitas 60 liter, padatkan setiap kali memasukan campuran cacahan batang pisang dan molases untuk mengeluarkan oksigen sebanyak mungkin. Pengisian silo fermentor dilakukan terus secara bertahap sampai bahan habis, lakukan penutupan menggunakan penutup silo fermentor dan simpan selama 21 hari. Setelah proses fermentasi selesai, tutup silo fermentor dibuka dan diganti dengan kain kasa, putar posisi silo fermentor sehingga bagian lubang berada di bawah dan berikan landasan agar posisi silo fermentor berdiri tegak, sebelumnya siapkan wadah penampung ekstrak cairan asam laktat (ekstrak cairan fermentasi anaerob). Ekstrak cairan asam laktat ditampung oleh wadah yang telah diletakan di bawah mulut silo fermentor, simpan ekstrak cairan asam laktat pada kondisi suhu $5^{\circ} \mathrm{C}$ (lemari pendingin), selanjutnya digunakan sebagai bahan aditif pada proses ensilase rumput Benggala.

\section{Proses pembuatan silase rumput Benggala}

Rumput Benggala dipanen awal masa berbunga pada umur sekitar 30 hari, dicacah pada ukuran panjang sekitar 3-5 cm, timbang sebanyak $40 \mathrm{~kg}$. Tebarkan cacahan rumput Benggala di atas alas plastik. Buat campuran antara molases dengan ekstrak cairan asam laktat sesuai perlakuan, yaitu perbandingan antara molases dengan ekstrak cairan asam laktat sebesar $(100 \%, 75 \%, 50 \%$, dan $25 \%$, $0 \%$ dengan $0 \%, 25 \%, 50 \%, 75 \%$ dan $100 \%$ ). Tiap campuran digunakan sebagai bahan aditif pada pembuatan silase rumput Benggala sesuai perlakuan yang telah ditetapkan. Timbang bahan aditif yang telah dibuat sesuai perlakuan sebanyak 5\% dari bobot cacahan rumput Benggala, dan siramkan secara merata di atas cacahan rumput Benggala. Aduk cacahan rumput Benggala dan bahan aditif sampai tercampur merata, masukan secara bertahap campuran rumput Benggala dan bahan aditif kedalam silo fermentor kapasitas 60 liter, padatkan setiap kali memasukan campuran cacahan rumput Benggala dan bahan aditif untuk mengeluarkan oksigen sebanyak mungkin.
Pengisian silo fermentor dilakukan terus secara bertahap sampai bahan yang akan difermentasi habis, lakukan penutupan menggunakan penutup silo fermentor dan simpan selama 21 hari. Sampel silase rumput Benggala yang dihasilkan diambil untuk dilakukan pengujian kualitasnya sesuai keperluan.

\section{Rancangan Percobaan dan Analisis Statistik}

Rancangan percobaan yang digunakan dalam penelitian ini adalah Rancangan Acak Lengkap dengan 5 (lima) perlakuan penambahan ekstrak cairan asam laktat (ECAL) produk fermentasi anaerob batang pisang, yaitu ; (1) P0M100 (0 \% ECAL + $100 \%$ molase), (2) P25M75 (25\% + $75 \%$ molase), (3) P50M100 (50\% ECAL + $50 \%$ molase), (4) P75M25 (75 $\%$ ECAL + $25 \%$ molase), (5) P100M0 (100 $\%$ ECAL + $0 \%$ molase), tiap perlakuan diulang sebanyak 4 kali. Peubah yang diukur adalah kualitas fisik dan kimia silase rumput Benggala, meliputi kebersihan, warna, bau, rasa, tekstur, derajat keasaman, kandungan asam laktat dan $\mathrm{NH}_{3}$. Data yang diperoleh diuji menggunakan analisis ragam dilanjutkan dengan uji Jarak Berganda Duncan (Duncan Multiple Range Test).

\section{HASIL DAN PEMBAHASAN}

\section{Kualitas Fisik Silase Rumput Benggala (Panicum maximum)}

Kualitas fisik silase rumput Benggala (Panicum maximum) pada berbagai taraf penambahan bahan aditif ekstrak cairan asam laktat (ECAL) produk fermentasi batang pisang, dicantumkan pada Tabel 1 .

Penambahan 25\% bahan aditif pada fermentasi anaerob (ensilage) batang pisang sampai $100 \%$ tidak memberikan pengaruh terhadap nilai kebersihan dan warna silase rumput Benggala. Penambahan ekstrak cairan asam laktat sampai $75 \%$ tidak menunjukkan perbedaan terhadap bau, rasa dan tekstur silase rumput Benggala, tetapi pada penambahan ekstrak cairan asam laktat sebanyak $100 \%$ menunjukan perbedaan bau, rasa dan tekstur silase rumput Benggala yang dihasilkan $(\mathrm{P}<0,05)$. 
Tabel 1. Kualitas fisik silase rumput Benggala (Panicum maximum)

\begin{tabular}{rlccccc}
\hline \multirow{2}{*}{ No } & \multirow{2}{*}{ Kualitas Fisik } & \multicolumn{5}{c}{ Perlakuan } \\
\cline { 2 - 6 } & P0M100 & P25M75 & P50M50 & P75M25 & P100M0 \\
\hline 1. & Warsihan & $4,00^{\mathrm{a}}$ & $3,50^{\mathrm{a}}$ & $4,00^{\mathrm{a}}$ & $4,00^{\mathrm{a}}$ & $2,50^{\mathrm{a}}$ \\
3. & Bau & $3,00^{\mathrm{a}}$ & $2,50^{\mathrm{a}}$ & $2,75^{\mathrm{a}}$ & $3,00^{\mathrm{a}}$ & $2,75^{\mathrm{a}}$ \\
4. & Rasa & $3,00^{\mathrm{a}}$ & $3,00^{\mathrm{a}}$ & $2,75^{\mathrm{a}}$ & $3,00^{\mathrm{a}}$ & $2,00^{\mathrm{b}}$ \\
5. & Tekstur & $3,00^{\mathrm{a}}$ & $3,00^{\mathrm{a}}$ & $2,75^{\mathrm{a}}$ & $3,00^{\mathrm{a}}$ & $2,25^{\mathrm{b}}$ \\
\hline
\end{tabular}

Keterangan : huruf yang sama pada baris yang sama menunjukan berbeda tidak nyata $(\mathrm{P}<0,05)$.

Tabel 2. Kualitas kimia silase rumput Benggala (Panicum maximum)

\begin{tabular}{clccccc}
\hline \multirow{2}{*}{ No } & \multirow{2}{*}{ Kualitas Kimia } & \multicolumn{5}{c}{ Perlakuan } \\
\cline { 3 - 6 } & & P0M100 & P25M75 & P50M50 & P75M25 & P100M0 \\
\hline 1. & Derajat keasaman $(\mathrm{pH})$ & $4,05^{\mathrm{a}}$ & $4,25^{\mathrm{b}}$ & $4,80^{\mathrm{c}}$ & $4,17^{\mathrm{d}}$ & $4,30^{\mathrm{be}}$ \\
2. & Kandungan asam laktat, \% & $0,45^{\mathrm{a}}$ & $0,56^{\mathrm{b}}$ & $0,70^{\mathrm{bc}}$ & $0,58^{\mathrm{bc}}$ & $0,43^{\mathrm{a}}$ \\
3. & $\mathrm{~N}^{\mathrm{c}} \mathrm{NH}_{3}, \mathrm{mM} /$ liter & $4,18^{\mathrm{a}}$ & $4,07^{\mathrm{a}}$ & $3,31^{\mathrm{bc}}$ & $2,60^{\mathrm{c}}$ & $3,08^{\mathrm{d}}$ \\
\hline
\end{tabular}

Keterangan : huruf yang sama pada baris yang sama menunjukan berbeda tidak nyata $(\mathrm{P}<0,05)$.

Kualitas fisik silase rumput Benggala yang meliputi bau, rasa dan tekstur silase yang dihasilkan mengalami penurunan nilai seiring dengan penambahan taraf cairan asam laktat. Kondisi ini terjadi karena bakteri asam laktat yang terdapat didalam ekstrak cairan asam laktat masih membutuhkan sumber energi yang dapat diperoleh dengan mudah dari molases yang ditambahkan untuk pertumbuhannya selama proses ensilase berlangsung.

Molases merupakan sumber karbohidrat mudah larut yang dapat dimanfaatkan oleh mikroba, termasuk bakteri asam laktat untuk perkembangbiakannya, seperti dikemukakan oleh Yunus et al. (2000), molases biasanya ditambahkan pada silase sebagai sumber gula sederhana atau karbohidrat mudah larut yang berfungsi untuk meningkatkan proses fermentasi pada ensilase hijauan pakan. Molases sebagai sumber karbohidrat mudah larut air (water soluble carbohydrate) pada proses ensilase rumput Benggala masih dibutuhkan untuk memacu perkembangan mikroba, walaupun jumlah kebutuhannya semakin kecil. Artinya, karbohidrat yang terdapat di dalam rumput Benggala, diduga belum cukup untuk memenuhi kebutuhan nutrisi bagi pertumbuhan mikroba.
Beberapa hasil penelitian menunjukkan bahwa sebagian rumput daerah tropis memiliki kandungan zat makanan, termasuk karbohidrat mudah larut air dengan konsentrasi yang relatif rendah (Mc. Donald et al., 1991, Yahya et al., 2004, Ridwan et al., 2005), sehingga jika rumput Benggala akan diawetkan dalam bentuk silase masih dibutuhkan penambahan bahan aditif yang dapat dimanfaatkan sebagai sumber karbohidrat mudah larut air pada takaran tertentu.

\section{Kualitas Kimia Silase Rumput Benggala (Panicum maximum)}

Indikator kualitas silase rumput Benggala (Panicum maximum) pada taraf penambahan $25 \%$ sampai $100 \%$ bahan aditif ekstrak cairan asam laktat (ECAL) produk fermentasi batang pisang, meliputi nilai derajat keasaman $(\mathrm{pH})$, kandungan asam laktat dan konsentrasi $\mathrm{N}-\mathrm{NH}_{3}$, dicantumkan pada Tabel 2.

Berdasarkan hasil analisis ragam pada data yang dihasilkan dari penelitian ini dapat diketahui bahwa penambahan ekstrak cairan asam laktat sampai taraf 50\% memberikan pengaruh terhadap kenaikan derajat keasaman $(\mathrm{pH})$ silase rumput Benggala (Panicum maximum), tetapi terjadi penurunan lagi setelah penambahan ekstrak cairan asam laktat 
sampai pada taraf $75 \%$, namun nilainya masih berada pada kisaran standard kualitas silase sangat baik. Kondisi yang sama terjadi pada kandungan asam laktat silase rumput Benggala yang dihasilkan, kandungan asam laktat tertinggi diperoleh pada perlakuan penambahan ekstrak cairan asam laktat sebesar $50 \%$.

Menurut Mc Donald et al. (1991), proses ensilase dengan penambahan bakteri asam laktat dapat menekan pertumbuhan jamur, meningkatkan kandungan asam laktat dan menurunkan kandungan $\mathrm{pH}$ dengan cepat. Hasil penelitian Yunus et al. (2000), menunjukkan bahwa inokulasi bakteri asam laktat dapat meningkatkan produksi asam laktat pada silase rumput gajah, baik yang dipotong pada umur yang masih muda maupun yang sudah dewasa.

Kandungan $\mathrm{N}-\mathrm{NH} 3$ pada silase rumput Benggala yang dihasilkan menunjukan penurunan sebanyak $20,81 \%$ pada perlakuan penambahan ekstrak cairan asam laktat sebesar $50 \%$, sampai $37,79 \%$ pada perlakuan penambahan ekstrak cairan asam laktat sebanyak $75 \%$, dibandingkan silase rumput Benggala tanpa penambahan ekstrak cairan asam laktat atau penambahan $100 \%$ molases. Penurunan kandungan $\mathrm{N}_{-} \mathrm{NH}_{3}$ pada silase rumput Benggala pada penelitian ini menunjukkan bahwa perlakuan penambahan ekstrak cairan asam laktat dapat menghambat penurunan kandungan protein dalam rumput Benggala, artinya molekul protein di dalam rumput Benggala tidak banyak mengalami perombakan oleh mikroba pada saat proses ensilase berlangsung. Kondisi ini terjadi karena asam laktat yang dihasilkan mampu menurunkan $\mathrm{pH}$ silase, sehingga enzim protease yang bekerja untuk menguraikan protein menjadi $\mathrm{N}-\mathrm{NH}_{3}$ semakin sedikit. Senyawa $\mathrm{N}-\mathrm{NH}_{3}$ dalam silase hijauan pakan merupakan senyawa yang dihasilkan akibat perombakan protein bahan pakan oleh aktifitas mikroba, terutama proteolisis.

Silase hijauan pakan yang berkualitas baik akan dihasilkan ketika fermentasi didominasi oleh bakteri yang menghasilkan asam laktat, sedangkan aktifitas bakteri klostridia rendah, jumlah bakteri asam laktat pada awal fermentasi merupakan faktor penting yang menentukan kualitas silase yang dihasilkan (Muck, 1989 dalam Santoso, 2009). Penambahan bakteri asam laktat hasil fermentasi sebanyak $1 \%$ (v/b) pada ensilase jerami padi segar menghasilkan peningkatan nilai koefisien cerna fraksi serat kasar dan konsentrasi asam lemak terbang total (Takahashi et al., 2005). Sedangkan penambahan $3 \%$ bakteri asam laktat hasil fermentasi pada rumput tropika dapat meningkatkan kualitas fermentasi silase, dengan ditandai oleh $\mathrm{pH}$ dan konsentrasi N-NH3 yang rendah (Santoso et al., 2009). Bakteri asam laktat secara alami sudah ada dalam tanaman sehingga dapat secara langsung berperan pada saat fermentasi, tetapi untuk mengoptimalkan hasil fase ensilase dianjurkan untuk melakukan penambahan aditif seperti inokulan bakteri asam laktat dan aditif lainnya untuk menjamin berlangsungnya fermentasi asam laktat yang sempurna (Ridwan et al., 2005).

Penambahan inokulan bakteri asam laktat yang berasal dari hasil fermentasi rumput Gajah pada jerami padi dapat meningkatkan konsentrasi asam laktat sampai 38,1\% dibandingkan perlakuan kontrol, jerami padi dengan inokulasi bakteri asam laktat asal fermentasi rumput Gajah menghasilkan kualitas fermentasi yang yang lebih baik dibandingkan dengan yang diberi inokulan bakteri asam laktat yang berasal dari fermentasi jerami padinya sendiri, dan pemberian silase jerami padi yang diinokulasi dengan bakteri asam laktat dari fermentasi rumput gajah tersebut pada kambing mampu meningkatkan kecernaan bahan kering, bahan organik dan protein dibandingkan dengan jerami padi tanpa inokulasi bakteri asam laktat (Santoso et al., 2012).

Standar kualitas kimia untuk silase hijauan pakan diantaranya meliputi nilai derajat keasaman, kandungan asam laktat dan konsentrasi $\mathrm{N}-\mathrm{NH}_{3}$. Silase hijauan pakan dengan standard sangat baik harus memiliki nilai keasaman antara 3- 4,2 (Mc Ilroy, 1977), kandungan asam laktat berkisar antara 1,5\%-2,5\% (Mc Ilroy, 1977; Mc Donald, 1986), sedang- 
kan konsentrasi $\mathrm{N}-\mathrm{NH}_{3}$ tidak lebih dari 5\%8\% dari jumlah $\mathrm{N}$ total (Mc Ilroy, 1977). Secara keseluruhan, hasil penelitian ini menunjukkan bahwa nilai derajat keasaman $(\mathrm{pH})$, kandungan asam laktat dan konsentrasi $\mathrm{N}-\mathrm{NH}_{3}$ silase rumput Benggala berada pada kisaran nilai untuk silase dengan kualitas sangat baik.

\section{KESIMPULAN}

Penambahan ekstrak cairan asam laktat produk fermentasi batang pisang memberikan pengaruh terhadap kualitas fisik dan kimia silase rumput Benggala, dan campuran ekstrak cairan asam laktat produk fermentasi batang pisang dengan molases pada perbandingan $75 \%$ : $25 \%$ menghasilkan kualitas fisik dan kimia silase rumput Benggala terbaik.

\section{DAFTAR PUSTAKA}

Aritonang, D., N.A. Tul Roefiah., T. Pasaribu., Y.C. Raharjo. 2003. Laju pertumbuhan kelinci Rex, Satin dan persilangannya yang diberi Lactosym ${ }^{\circledR}$ dalam sistem pemeliharaan intensif. JITV. 8(3).

Mc Donald, P., N. Henderson., S. Heron. 1991. The Biochemistry of Silage. Second Edition. Chalombe Publication.

Mc Ilroy R.J. 1977. Pengantar Budidaya Padang Rumput Tropika. Cetakan kedua. Pradnya Paramita. Jakarta.

Hartadi, H., S. Reksohadiprodjo., A.D. Tillman. 1990. Tabel Komposisi Pakan Untuk Indonesia. Gadjah Mada University Press, Yogyakarta.

Ridwan R., S. Ratnakomala., G. Kartina., dan Y. Widiastuti. 2005. Pengaruh penam- bahan dedak padi dan Lactobasillus plantarum 1 BL-2 dalam pembuatan silase rumput gajah (Pennisetum purpureum). Med. Peternakan. 28(3): $117-123$.

Santoso B., B. Tj. Hariadi., H. Manik., dan H. Abubakar. 2009. Kualitas rumput unggul tropika hasil ensilase dengan bakteri asam laktat dari ekstrak rumput terfermentasi. Med. Peternakan. 32(2): $137-144$.

Santoso B., Tj. Hariadi., Alimuddin., and D. Y. Seseray. 2012. Fermentation characteristics of rice crop residu based silage treated by epiphytic and commercial LAB. Med. Peternakan 35 (1): 60-66.

Takahashi, T., K. Horiguchi and M. Goto. 2005. Effects of crussing unhulled rice and the addition of fermented juice of epiphytic lactic acid bacteria on the fermentation quality of whole crop rice silase, and its digestibility and rumen fermentation status in sheep. J. Anim Sci. 76, pp. $353-358$.

Yahya, M.S., M. Goto., W. Yimiti., B. Smerjai and Y. Kuwamoto. 2004. Evaluation of fermentation quality of a tropical and temperate forage crops ensiled with additive of fermented juice of epiphytic lactic acid bacteria. Asian Aust. J. Anim. Sci. Vol. 17. Pp. $942-$ 946.

Yunus M., N. Ohba., M. Shimojo., M. Furuse., and Y. Masuda. 2000. Effects of adding urea and molasses on napier grass silage quality. Asian - Aus. J. Anim Sci. 13(11): 1542 - 1547. 